\title{
ANALISIS PERMINTAAN PRODUK PETERNAKAN DI DESA TAWAANG KECAMATAN TENGA KABUPATEN MINAHASA SELATAN
}

\author{
Reynol Loho*, B. Rorimpandey**, M. T. Massie**, N. Santa** \\ Fakultas Peternakan Universitas Sam Ratulangi, Manado, 95115
}

\begin{abstract}
ABSTRAK
Tujuan penelitian ini ialah untuk mengetahui jumlah permintaan produk peternakan di Kecamatan Tenga. Permasalahannya, sejauh mana harga daging ayam, harga daging babi, harga daging sapi, harga ikan, harga tahu dan harga tempe mempengaruhi tingkat permintaan produk peternakan di Kecamatan Tenga. Jumlah sampel yang diambil sebanyak 45 rumah tangga responden. Waktu penelitian dan pengumpulan data selama 3 bulan dengan menggunakan metode survey. Analisis data yang digunakan adalah model SUR (Seemingly Unrelated Regression) dengan pendekatan fungsi permintaan. Hasil penelitian menunjukkan jumlah permintaan produk peternakan di Kecamatan Tenga yaitu: daging ayam sebesar 3,04 kg/triwulan, daging babi sebesar $3,24 \mathrm{~kg} /$ triwulan, daging sapi sebesar $1,29 \mathrm{~kg} /$ triwulan, telur sebesar 64,56 butir/triwulan. Kesimpulannya, faktor harga daging ayam, harga daging babi, harga daging sapi serta harga ikan, harga tahu dan harga tempe ikut mempengaruhi jumlah permintaan produk peternakan.
\end{abstract}

Kata Kunci : Permintaan, harga, telur, daging

\section{ABSTRACT}

\section{ANALYSIS OF LIVESTOCK PRODUCT DEMAND AT TAWAANG VILLAGE, TENGA DISTRICT SOUTH MINAHASA REGENCY. The purpose of this study was to determine the number of}

*Alumni Fakultas Peternakan Unsrat **Jurusan Sosial Ekonomi Peternakan livestock product demand in Tenga district. The problem this study was how far demand factors such as prices of chicken meat, pork, beef meat, fish, tofu and fermented soybean (tempe) affected the level of demand for livestock products in Tenga district.The total number of samples used in this study were 45 respondents of households. Data collection was conducted during 3 months using the survey method. The analysis used was the model of SUR (Seemingly Unrelated Regression) using the equation of the demand function. The results showed that the numbers of livestock product demand in the Tenga district were chicken meat of 3.04 $\mathrm{kg} /$ quarter, pork of $3.24 \mathrm{~kg} /$ quarter, beef of $1.29 \mathrm{~kg}$ /quarter, and egg product of 64.56 eggs/quarter. Therefore; factor of the prices of chicken meat, pork, beef, fish, tofu and fermented soybean (tempe) influenced the demand of livestock products.

Keywords: Demand, prices, animal product.

\section{PENDAHULUAN}

Produk peternakan berupa daging dan telur mempunyai nilai gizi yang baik, seperti daging terdiri dari $13 \%$ protein, $67 \%$ air, $8 \%$ karbohidrat, dan $25 \%$ air, telur terdiri dari $(72,8-75,6 \%)$ air, $(12,8$ - $13,4 \%)$ protein dan $(10,5-1,8 \%)$ lemak. Menurut Setiawan (2006), daging dan telur sangat penting untuk dikonsumsi oleh tubuh. Selain 
rasanya lezat, pengolahannya yang cukup beragam, mudah dicerna dan diserap tubuh untuk membangun jaringan-jaringan tubuh agar bisa berkembang dengan baik dan sehat. Nutrisi yang dikandung pun hampir sempurna. Anak-anak yang masih dalam masa pertumbuhan sangat memerlukan protein. Peningkatan konsumsi protein asal ternak sangat dibutuhkan karena rendahnya konsumsi protein asal ternak berdampak pada tingkat kecerdasan dan kualitas hidup penduduk Indonesia (Rusfidra, 2002). Peningkatan produksi produk peternakan perlu dilakukan sehingga ketersediaan produk peternakan bisa seimbang dengan permintaan masyarakat. Semakin banyak masyarakat yang mengkonsumsi produk peternakan maka semakin banyak jumlah sumber daya manusia berkualitas yang dapat bekerja optimal dalam pembangunan ekonomi. Menurut Sukirno (2005), terdapat beberapa faktor-faktor yang dapat mempengaruhi jumlah permintaan suatu barang oleh konsumen. Faktor-faktor tersebut yaitu: harga barang itu sendiri, harga barang lain yang berkaitan erat dengan barang tersebut, pendapatan, cita rasa (selera) dan jumlah penduduk.

Kecamatan Tenga merupakan salah satu kecamatan yang berada di Kabupaten Minahasa Selatan yang terdiri dari 18 (delapan belas) desa dengan jumlah kepala keluarga (KK) adalah 4.402 serta 17.378 jiwa (BPS Kabupaten Minahasa Selatan, 2011). Pertanian menjadi sektor andalan penduduk Kecamatan Tenga sebagai sumber mata pencaharian, sebagian kecil bekerja sebagai sopir, pedagang dan pegawai negeri. Sedangkan dalam pemenuhan kebutuhan akan protein hewani, tidak lepas dari berbagai faktor yang mempengaruhi permintaan seperti : harga barang itu sendiri, harang barang lain, selera, jumlah penduduk dan juga pendapatan.

Berdasarkan pemikiran dan latar belakang di atas, perlu diketahui lebih lanjut sejauh mana pengaruh harga barang itu sendiri, harga barang lain dan jumlah pendapatan mempengaruhi jumlah permintaan produk peternakan yang ada di Kecamatan Tenga. Rumusan masalah yaitu sejauh mana faktor-faktor harga daging ayam, harga daging babi, harga daging sapi, harga ikan, harga tahu dan harga tempe mempengaruhi 
tingkat permintaan produk peternakan di Kecamatan Tenga.

Penelitian ini bertujuan untuk mengetahui jumlah permintaan produk peternakan di Kecamatan Tenga serta menganalisis apakah faktor harga daging ayam, harga daging babi, harga daging sapi, harga ikan, harga tahu dan harga tempe turut mempengaruhi permintaan produk peternakan di Kecamatan Tenga.

\section{METODE PENELITIAN}

Penelitian ini dilaksanakan di Kecamatan Tenga Kabupaten Minahasa Selatan. Metode penelitian yang digunakan adalah metode survei. Jenis data yang akan diperoleh yaitu dari data primer dan data sekunder. Penentuan lokasi (desa sampel) dalam penelitian ini dilakukan secara Purposive sampling (Iskandar, 2009) . dengan pertimbangan sebagai berikut:

1. Desa tersebut memilki jumlah penduduk terbanyak

2. Desa tersebut dapat mewakili secara keseluruhan dari data yang akan diambil, karena jumlah penduduk desa tersebut sebanyak 2.552 jiwa.
Berdasarkan pertimbangan tersebut, maka yang menjadi desa sampel dalam penelitian yaitu desa Tawaang Raya. Sedangkan untuk penentuan 45 responden, dilakukan secara Simple Random Sampling (Arikunto, 2002 dan Daniel 2001) yaitu sampel yang di ambil secara acak sederhana sebanyak 10\% dari jumlah rumah tangga (KK) pada desa sampel.

Definisi variabel penelitian dan pengukurannya dalam penelitian ini menyangkut (1) Permintaan; (2) Harga barang itu sendiri; (3) Harga barang lain; (4) Harga daging sapi; (5) Harga daging ayam; (6) Harga daging babi; (7) Harga telur ayam ras; (8) Pendapatan.

Data yang dikumpulkan dianalisis dengan menggunakan model SUR (Seemingly Unrelated Regression). Model SUR dapat diestimasi menggunakan beberapa metode antara lain metode Maximun Likelihood, Generalized Least Square (GLS) dan Feasible Generalized Least Square (FGLS), dengan menggunakan persamaan dari fungsi permintaan.

$$
\begin{aligned}
& \mathrm{Qd}=\mathrm{a}+\mathrm{b}_{1} \mathrm{P}_{\mathrm{d}}+\mathrm{b}_{2} \mathrm{P}_{\mathrm{s}}+\mathrm{d}_{1} \mathrm{D}_{1}+ \\
& \mathrm{d}_{2} \mathrm{D}_{2}+\mathrm{e} \ldots \ldots \ldots \ldots \ldots \ldots(2)
\end{aligned}
$$


Keterangan :

Qd = jumlah barang yang diminta, (kg/tahun)

Ket: Qd1= daging ayam; Qd2= daging babi; Qd3= daging sapi

$$
\begin{aligned}
& \mathrm{a}=\text { konstanta } \\
& b_{1}, b_{2}, b_{3}=\text { koefisien variabel } \\
& \mathrm{P}_{\mathrm{d}} \quad=\text { harga barang yang } \\
& \mathrm{P}_{\mathrm{s}} \quad=\text { harga barang } \\
& \text { pengganti, yaitu harga } \\
& \text { ikan, harga tahu dan } \\
& \text { harga tempe }(\mathrm{rp} / \mathrm{kg}) \\
& \mathrm{d}_{1}, \mathrm{~d}_{2}=\text { koefisien dummy } \\
& \text { variabel pendapatan rumah } \\
& \text { tangga } \\
& \mathrm{D}_{1} \quad=\text { dummy variabel } \\
& \text { pendapatan rumah tangga } \\
& \text { kategori sedang }
\end{aligned}
$$

$\mathrm{D}_{1}=1, \quad$ rumah tangga berpendapatan sedang $\mathrm{D}_{1}=0, \quad$ rumah tangga berpendapatan selain sedang $\mathrm{D}_{2} \quad=$ dummy variabel pendapatan rumah tangga kategori tinggi

$\mathrm{D}_{2}=1$, rumah tangga berpendapatan tinggi

$$
\mathrm{D}_{2}=0, \quad \text { rumah tangga }
$$$$
\text { berpendapatan selain tinggi }
$$$$
\mathrm{e} \quad=\text { Tingkat kesalahan }
$$

\section{HASIL DAN PEMBAHASAN}

Permintaan adalah hubungan antara jumlah suatu barang yang mau dibeli dengan harga barang itu (Gilarso, 2003). Konsumen mau "meminta" (dalam pengertian ekonomi) suatu barang pada harga tertentu karena barang tersebut dianggap berguna baginya. Makin rendah harga suatu barang maka konsumen cenderung untuk membelinya dalam jumlah yang lebih besar. Menurut Hanafie (2010), permintaan adalah jumlah dari suatu barang yang mau dan dapat dibeli konsumen pada berbagai kemungkinan harga, dalam jangka waktu tertentu, dengan anggapan halhal lain tetap sama (cateris paribus). Demikian juga permintaan di desa Tawaang Kecamatan Tenga, apabila harga produk peternakan (daging dan telur) naik, maka masyarakat akan cenderung mengurangi permintaannya. Sebaliknya jika harga turun maka masyarakat cenderung meningkatkan permintaannya. Perkembangan permintaan produk peternakan di 
Kecamatan Tenga dapat dilihat pada Tabel 1.

Data Tabel 1 menunjukkan bahwa, permintaan produk peternakan berupa daging ayam, daging babi dan daging sapi di desa Tawaang Kecamatan Tenga dari bulan Oktober sampai Desember mengalami kenaikan. Sedangkan untuk produk peternakan berupa telur mengalami penurunan di bulan November. Pada bulan Oktober sampai November, daging ayam naik sebesar 18\%, daging babi naik sebesar $1 \%$, daging sapi naik sebesar $7 \%$ dan telur mengalami penurunan sebesar $15 \%$ dari bulan Oktober.

Tabel 1. Permintaan Produk peternakan di Kecamatan Tenga

\begin{tabular}{ccccc}
\hline Bulan & Daging Ayam & Daging Babi & Daging Sapi & Telur \\
\hline Oktober & 1,96 & 2,27 & 0,84 & 8,40 \\
November & 2,40 & 2,31 & 0,91 & 7,29 \\
Desember & 4,76 & 5,13 & 2,11 & 48,87 \\
\hline
\end{tabular}

Menurut Mubyarto (1989), yang dimaksud dengan harga adalah nilai dari barang-barang dan jasa. Sedangkan menurut Mujiyanto (2001), harga adalah jumlah uang yang menyatakan nilai tukar suatu kesatuan benda tertentu. Harga turut mempengaruhi jumlah produk peternakan berupa daging dan telur.

Konsumen akan membeli suatu barang dengan jumlah yang banyak, apabila barang tersebut murah. Sebaliknya, konsumen akan mengurangi pembelian terhadap suatu barang apabila barang tersebut mahal. Hal ini sejalan dengan Gilarso (2003), yang menyatakan bahwa kuantitas barang yang diminta untuk suatu barang berhubungan terbalik dengan harga barang tersebut, cateris paribus. Harga suatu barang atau jasa yang semakin rendah, semakin tinggi tingkat permintaan akan barang atau jasa tersebut. Sebaliknya, apabila harga barang atau jasa tersebut semakin tinggi, tingkat permintaan akan barang atau jasa tersebut akan semakin rendah. Perkembangan harga produk peternakan di Kecamatan Tenga dapat dilihat pada Tabel 2.

Data pada Tabel 2 menunjukkan bahwa harga produk peternakan berupa daging babi dan daging sapi di Kecamatan Tenga mengalami kenaikan dari bulan 
Oktober sampai Desember. Harga daging ayam bulan November mengalami penurunan, dan pada bulan Desember mengalami kenaikan. Produk peternakan berupa telur dari bulan Oktober sampai November tidak mengalami perubahan harga, sedangkan pada bulan Desember mengalami kenaikan. Harga daging babi mengalami kenaikan sebesar $11 \%$, harga daging sapi naik sebesar $4,7 \%$ sedangkan harga daging ayam mengalami penurunan sebesar $18,7 \%$ pada bulan November.

Tabel 2. Perkembangan Harga Produk Peternakan di Kecamatan Tenga

\begin{tabular}{ccccc}
\hline Bulan & $\begin{array}{c}\text { Harga daging } \\
\text { babi }\end{array}$ & $\begin{array}{c}\text { Harga daging } \\
\text { ayam }\end{array}$ & $\begin{array}{c}\text { Harga daging } \\
\text { sapi }\end{array}$ & Telur \\
\hline Oktober & 40000 & 38000 & 80000 & 1500 \\
November & 45000 & 32000 & 84000 & 1500 \\
Desember & 48000 & 45000 & 90000 & 1800 \\
\hline
\end{tabular}

Pada bulan Desember harga daging babi, ayam, sapi dan telur mengalami kenaikan yang cukup signifikan. Harga daging babi mengalami kenaikan sebesar 6,25\%, harga daging ayam naik sebesar 28,8\%, harga daging sapi juga naik sebesar $6,6 \%$ dan harga telur naik sebesar 16,6\%. Hal ini disebabkan oleh banyaknya jumlah permintaan pada bulan Desember,yang merupakan hari raya besar umat kristiani. Hasil analisis data
menggunakan didapatkan persaaman permintaan daging ayam, daging babi dan daging sapi sebagai berikut:
Permintaan Daging Ayam ;

$$
\begin{aligned}
& Q_{\text {daging ayam }}=130,4029+ \\
& \text { 0,0006P.ayam }-0,0000075 \text { P.babi } \\
& \text { - 0,0021P.sapi }+ \text { 0,001P.ikan }+ \\
& \text { 0,001P.tahu }- \text { 0,0008P.tempe + } \\
& \text { 0,76d1 + 3,19d2 } \\
& \boldsymbol{R}^{\mathbf{2}}=0,4845 \text { atau 48.45\% } \\
& \overline{\boldsymbol{R}^{\mathbf{2}}}=0,3700
\end{aligned}
$$

Permintaan Daging Babi;

$$
\begin{aligned}
& Q_{\text {daging babi }}=-121,151 \\
& \text { 0,0017P.ayam }+ \text { 0,0013P.babi }+ \\
& \text { 0,0015P.sapi }+\quad \text { 0,00028P.ikan } \\
& \text { - 0,0015P.tahu }+ \text { 0,0029P.tempe } \\
& + \text { 1,67d1+ 0,65d2 } \\
& \boldsymbol{R}^{2}=0,2918 \text { atau 29,18\% } \\
& \overline{\boldsymbol{R}^{\mathbf{2}}}=0,1345
\end{aligned}
$$


Permintaan Daging Sapi;

$$
\begin{aligned}
& Q_{\text {daging sapi }}=189,2615 \\
& \text { 0,0013Payam }+ \text { 0,00027Pbabi - } \\
& \text { 0,0017Psapi - 0,0001Pikan - } \\
& \text { 0,00002Ptahu }-0,001 \text { Ptempe + } \\
& \text { 0,94d1 + 0,90d2 } \\
& \boldsymbol{R}^{2}=0,6299 \text { atau 62,99\% } \\
& \overline{\boldsymbol{R}^{2}}=0,5477
\end{aligned}
$$

Nilai $\boldsymbol{R}^{\mathbf{2}}$ adalah nilai $\mathrm{R}$ square yang menyatakan presentase pengaruh variabel-variabel independen dalam penelitian ini, yang mempengaruhi variabel dependen. Nilai $\overline{\boldsymbol{R}^{2}}$ adalah nilai adjusted $\mathrm{R}$ square yang menyatakan hubungan antara nilai $\boldsymbol{R}^{\mathbf{2}}$ dengan nilai $\overline{\boldsymbol{R}^{2}}$, apabila nilai perbedaan antara keduanya makin kecil maka hubungan antar regresi makin baik.

\section{KESIMPULAN DAN SARAN}

Berdasarkan hasil penelitian dapat disimpulkan bahwa :

1. Jumlah permintaan produk peternakan di Kecamatan Tenga yaitu ; (a). Daging ayam sebesar 3,04 kg/triwulan; (b).Daging babi sebesar 3,24 kg/ triwulan (c). Daging sapi sebesar $1,29 \mathrm{~kg} /$ triwulan dan (d). Telur sebesar 64,56 butir/triwulan
2. Faktor harga daging ayam, harga daging babi dan harga daging sapi serta harga barang lain ikut mempengaruhi jumlah permintaan produk peternakan di desa Tawaang Kecamatan Tenga Kabupaten Minahasa Selatan.

Perlu dilakukan penelitian lebih lanjut, karena selain faktor harga barang itu sendiri dan faktor harga barang lain, masih ada faktor yang lain yang turut mempengaruhi permintaan produk peternakan berupa daging dan telur, antara lain: faktor selera, jumlah penduduk dan pendapatan.

\section{DAFTAR PUSTAKA}

Arikunto, S. 2002. Prosedur Penelitian, Suatu Pendekatan Praktek. Edisi Revisi V. Bina Aksara. Yogyakarta.

BPS Minahasa Selatan. 2011. Minahasa Selatan Dalam Angka. Badan Pusat Statistik Kabupaten Minahasa Selatan. Daniel, M. 2001. Metode Penelitian Sosial Ekonomi. Umi Aksara 
Gilarso, T. 2003. Pengantar ilmu ekonomi mikro. KANISIUS. Yogyakarta.

Hanafie, R. 2010. Pengantar ekonomi pertanian. CV.Andi. Yogyakarta.

Iskandar. 2009. Metode Penelitian Pendidikan dan Sosial (Kuantitatif dan Kualitatif). Gaung Persada Press. Jakarta

Mubyarto. 1989. Pengantar Ekonomi Pertanian. LP3ES, Jakarta.

Mujiyanto. 2001.Analisis Permintaan Daging Sapi di Kota Manokwari. Fakultas Pertanian Universitas Cendrawasih, Manokwari.

Rusfidra. 2002. "Peranan pendidikan tinggi jarak jauh untuk mewujudkan knowledge based society", Jurnal Pendidikan dan Kebudayaan. Badan Penelitian dan Pengembangan Depdiknas. Jakarta.

Setiawan. N. 2006. Perkembangan Konsumsi Protein Hewani di Indonesia: Analisis Hasil Survei Sosial Ekonomi
Nasional 2002-2005.

Fakultas Peternakan

Universitas Padjajaran.

Bandung.

Sukirno,S. 1994. Pengantar Mikro Ekonomi. PT Raja Grafindo Persada, Jakarta 
